\title{
AN ENHANCED TECHNO-ECONOMIC ANALYSIS OF LCOE: PUBLIC INCENTIVES VS PRIVATE INVESTMENT
}

\author{
Rogelio PEÓN MENÉNDEZ ${ }^{1}$, Alejandro PARRA MARTÍN ${ }^{1}$, \\ Laura VARELA-CANDAMIO (D2* ${ }^{*}$, María-Teresa GARCÍA-ÁLVAREZ (D) 3 \\ ${ }^{1}$ Technology Department, Energy, TSK Group, Gijón, Spain \\ ${ }^{2}$ Department of Economics, Faculty of Economics and Business, \\ University of A Coruna, A Coruna, Spain \\ ${ }^{3}$ Department of Business, Faculty of Economics and Business, \\ University of A Coruna, A Coruna, Spain
}

Received 27 September 2018; accepted 30 June 2019

\begin{abstract}
This paper offers a new approach for the estimation of levelized cost of energy (LCOE) by considering the shareholder internal rate of return (IRR) as an unexplored measure in this kind of analysis. The study relies on a comprehensive techno-economic evaluation based on interactions among a set of factors. This mathematical model is then empirically tested for a CSP power plant in Extremadura (Spain) due to their dominant market position and also for being the most developed renewable system at the present. A sensitivity analysis is also performed to establish the influence that market conditions have on the determination of LCOE for different scenarios under the maintenance of a given shareholder IRR for investors. This last assumption makes investment decisions indifferent among several projects in order to focus solely on the minimization of the LCOE. Results reveal that while the annual net electricity production contributes to the reduction of LCOE, total investments, equity percentage and operation and maintenance (O\&M) costs help to increase their value by a high percentage. This study gives important scientific basis for investment decision making and also becomes a standpoint to design suitable public incentives that may enhance future technological developments in the CSP generation industry.
\end{abstract}

Keywords: renewable energy, levelized cost of energy, CSP energy, shareholder returns, public policy, Spain.

JEL Classification: K32, O13, H30.

\section{Introduction}

The goal of sustainable development compatible with the growing demand for electricity generated as a consequence of population growth worldwide represents one of the greatest global challenges in recent times. For this reason, it is essential to search for alternatives to the more traditional energies that generate greenhouse gases and, eventually, the degrada-

*Corresponding author. E-mail: laura.varela.candamio@udc.es

Copyright (c) 2020 The Author(s). Published by Vilnius Gediminas Technical University

This is an Open Access article distributed under the terms of the Creative Commons Attribution License (http://creativecommons. org/licenses/by/4.0/), which permits unrestricted use, distribution, and reproduction in any medium, provided the original author and source are credited. 
tion of the environment. Renewable energies (RE), which limit the effects of climate change and global warming, can be a solution to address all these issues (Tian \& Zhao, 2013). In a business context of minimization of production costs and new market opportunities, solar energy emerges as a substitute source capable to compete with the new-build fossil fuel (International Energy Agency [IEA], 2014). In particular, concentrated solar power (CSP) plants are especially interesting in economies with growing capacity needs because the builtin storage of this technology can be easily integrated and, unlike other RE, dispatchable (Liu et al., 2016).

In most developed countries, governments and other stakeholders involved in the energy sector are aware of the feasibility of making the renewable economy a reality both technically and economically. The transition to the use of nearly $100 \%$ energy produced by renewable sources is not only possible by 2050 but also cost-effective, providing clean energy accessible to the global economy ${ }^{1}$. Thus, for decades, the public support in the promotion of renewable sources jointly with private technological improvements resulting in cost reductions and industrial dynamics led to a paramount growth of solar energy (Timilsina, Kurdgelashvili, \& Narbel, 2012). Despite these rapid developments, market and policy frameworks need to evolve in these technologies in order to cope simultaneously the provision of long-term price signals to attract investment, the strengthening of efficient short-term electricity dispatching, the measurement of negative externalities and the existence of sufficient levels of flexibility (IEA, 2017).

Spain is a European dominant country in the technological development of electricity generation from RE sources and, particularly, it is playing the leading position worldwide regarding the CSP technologies. By 2012, the solid economic-legal system, the involvement of stakeholders and also sub-central governments, and technical and economic private operators of the system as well as other related companies were especially remarkable factors (Ruiz Romero, Colmenar Santos, \& Castro Gil, 2012). However, since then, the public incentives have phased out and the national government support has hardly decreased in the RE sector in order to gain unbiased insights into the economic performance under steadily decreasing investment cost. The acceleration of this adjustment occurred unexpectedly and led to a sudden paralysis in the development of the Spanish sector, incapable to follow a new resilient pathway as other countries did, like Germany (Martínez Alonso et al., 2016).

After the disappearance of the support of policy makers in the promotion of the RE market it is crucial that, in the absence of public subsidy schemes, the generation of energy becomes commercially viable (Schleicher-Tappeser, 2012). This scenario calls for the empowerment of stakeholders in the implementation process goal in order to prevent a small group of authoritative agents composed mainly of multinationals and governments can manipulate the energy sector and generate higher systemic instability in the system (Martínez Alonso et al., 2016). This evaluation requires a systematic analysis of quantitative business projects and also a detailed research based on calculations of the cost of capital and its influence on the realization and financing of the project (Pawel, 2014).

\footnotetext{
${ }^{1}$ For instance, RE shares in the EU energy roadmaps were decided through binding targets by 2020 and, also, in the United States, President Obama's agenda included objectives based on the emphasis on similar purposes.
} 
The development and commercialization of new solar technologies may constitute a significant cost saving within a scenario where the cost of conventional electricity is constantly increasing. Enhanced solar technologies could achieve, in this way, large-scale grid parity in the coming years (Lund, 2011). This is another reason that justifies the enormous interest of a large number of stakeholder groups in following those improvements in CSP, with a quantitative precision that entails in turn a great value (Nemet \& Kammen, 2007). In order to provide reliable information to investors and funding agents regarding their expected returns as well as to regulators and policy makers about the economic outcomes related to energy production, a technical-economic method is required for all those actors to analyze proposed technology developments and, eventually, to adequately evaluate the cost of energy. The LCOE is expected to be the desirable instrument to measure it.

This paper outlines a new approach in the methodology to measure the LCOE by considering not only the project internal rate of return but the shareholder IRR. Other studies have also taken into account considered the project IRR but not that of the shareholder, that is, they consider the fixed charge rate (FCR, hereafter) as a given value. The algorithm developed under this new approach is related to the viability of the investment. In this way, the shareholder IRR variable is determined in order to measure the potential returns obtained for shareholders as an endogenous variable. Besides, this framework also permits the alteration characteristics in different input factors to be analyzed. Then, this model calculates the LCOE as the price of energy that must to be offered in the market to break even over the lifetime of the technology. This question is essential for cases of tenders in which the RE project is carried and companies must offers the cheapest LCOE. For this reason, the knowledge of the price is paramount: knowing the LCOE at which they can sell electricity, they can perfectly adjust the tender proposal. As a case study, this enhanced theoretical model is developed to a $50 \mathrm{MW}$ parabolic trough CSP power plant with 14-hour thermal storage (with molten salts) located in Extremadura (Spain), although the methodology can be applicable to other scenarios (for instance, other types of technologies such as photovoltaic, wind power, etc. in Spain or in other countries) and even to other methodologies like TES system, fuel backup system, co-firing, etc.

The paper is structured according to the following sections. After the introduction, Section 1 gives an outline of the literature review about the insights of LCOE for RE with a special focus on CSP plants. Section 2 describes the methodology through an enhanced framework as a novelty for the measurement of LCOE by including both project IRR and shareholder IRR. Section 3 applies the enhanced LCOE model for concentrated solar power plants as a case of study by including a sensibility analysis under different economic factors in order to maintain the shareholder IRR inalterable. Section 4 presents a discussion and interpretation of results obtained and also offers some public policy recommendations regarding these RE. Then, the conclusion section summarizes the main contributions of the paper.

\section{Literature review}

Since solar energy is the most abundant source of energy, the implementation and development of this type of technologies may turn out to be the best option for the production of clean energy worldwide (Darling, You, Veselka, \& Velosa, 2011). CSP plants, especially 
the ones using parabolic trough-concentrating solar power (PT-CSP) ${ }^{2}$, has been the most commercially-attractive option over the past few decades (Zhang, Baeyens, Degrève, \& Cacères, 2013). Thus, although CSP plants are widely installed and operated in the United States and Spain (IEA, 2014), these technologies still occupy a very small percentage of the global electricity production. The lack of production is due to their relatively higher costs, both the initial costs (approximately, between RMB27.73/W and RMB57.44/W) and also the generation costs, in comparison with the traditional energies like coal, fossil fuel or natural gas power (Caldés, Varela, Santamaría, \& Sáez, 2009). Nevertheless, advanced technology and the deployment of market scale are expected to reduce the costs of CSP in the future and, eventually, to reach power grid parity with the conventional ones (Dieter \& González, 2014); also bearing in mind considerable hidden costs identified with fossil fuels that are frequently not taken into account such as global warning or pollution (National Research Council [NRC], 2010).

There have been previous research that conducted the technical and economic evaluation of CSP generation. Table 1 summarized the main studies carried out in the last years. In this sense, the hybridization of solar energy technologies with other conventional power configurations (especially photovoltaic-CSP, or simply, PV-CSP) also emerges as a feasible framework to diminish the LCOE of CSP while increasing their efficiency. For instance, Spelling and Laumert (2015) developed a techno-analysis study of several combined processes of hybrid cycle power plants with CSP configurations or other solar technologies in order to find the optimal combination concerning benefits and also environmental pollution. Nevertheless, it lacks effective strategies to be applied in the market under changing conditions. Parrado, Girard, Simon, and Fuentealba (2016) calculated the LCOE of PV-CSP hybrid plant based on different scenarios for the period 2014 and 2050. More specifically, Silinga and Gauché (2014) studied the viability to operate peak-load power storage within CSP plants in South America. They found a feasible solution by using a hybrid system with gas turbines of diesel open cycle, being able to drop the LCOE in comparison with diesel peaking power plants by $45 \%$. In turn, Silinga, Gauché, Rudman, and Cebecauer (2015) performed a double tariff scheme under an enhanced performance based on the optimization of the CSP system. However, this analysis may need a broad presence of performance indicators since the solely factors used to evaluate the viability of the plant configuration was the LPOE, that is, the Levelised Profit of Energy.

Under the design of any power generation cost calculation model, the estimation of LCOE is indispensable (Hernández-Moro \& Martínez-Duart, 2013). Notice that there are some number of investigations in discussing the cost-benefit of distinctive energy system under a LCOE perspective, it is clearly seen however that those are lacking financial indexes, such as net present value (NPV), payback period, or internal rate of return (IRR) (Yang et al., 2018). Thus, in the above studies, system cost and O\&M cost are usually considered because they make up the most significant part of the total cost of a project. However, other variables such as interest payments and tax expenditures are disregarded by most of the researchers even when they present a largely impact on the cost structure of CSP systems over their eco-

\footnotetext{
2 There are four available technologies nowadays for concentrating solar power (CSP), namely parabolic trough (PT), linear Fresnel (LF), solar tower (ST) and parabolic dish (PD), and the heat transfer fluids mainly include water, thermal oil, molten salt, all solid state concrete and air.
} 
Table 1. Empirical research on the cost structure of CSP system

\begin{tabular}{|c|c|c|c|}
\hline Reference & $\begin{array}{l}\text { Country } \\
\text { of analysis }\end{array}$ & $\begin{array}{l}\text { Power system } \\
\text { analysis }\end{array}$ & Characteristics \\
\hline $\begin{array}{l}\text { Reichling and } \\
\text { Kulacki (2008) }\end{array}$ & USA & $\begin{array}{l}\text { Hybrid wind-solar power } \\
\text { plant vs Wind-only plant: } \\
\text { two case studies }\end{array}$ & $\begin{array}{l}\text { Performance analysis (comparative) } \\
\text { using market and retail value } \\
\text { of energy, and LCOE }\end{array}$ \\
\hline $\begin{array}{l}\text { I. Purohit and } \\
\text { P. Purohit }(2010)\end{array}$ & India & $\begin{array}{l}\text { CSP technologies: two case } \\
\text { studies }\end{array}$ & $\begin{array}{l}\text { Techno-economic analysis: } \\
\text { identifying niche areas }\end{array}$ \\
\hline $\begin{array}{l}\text { Hernández-Moro } \\
\text { and Martínez- } \\
\text { Duart (2013) }\end{array}$ & $\begin{array}{l}\text { Global } \\
\text { general } \\
\text { data }\end{array}$ & $\begin{array}{l}\text { PV vs CSP technologies: grid } \\
\text { parities }\end{array}$ & $\begin{array}{l}\text { Performance analysis (comparative) } \\
\text { using LCOE: identifying best } \\
\text { locations (latitudes) }\end{array}$ \\
\hline $\begin{array}{l}\text { Wagner and Rubin } \\
\text { (2014) }\end{array}$ & USA & $\begin{array}{l}\text { CSP (parabolic trough) plant } \\
\text { operating with: TES, natural } \\
\text { gas-fired backup, and no } \\
\text { backup }\end{array}$ & $\begin{array}{l}\text { Performance, cost and profit } \\
\text { (comparative) analysis among } \\
\text { systems: revealing the importance } \\
\text { of TES system }\end{array}$ \\
\hline $\begin{array}{l}\text { Guédez, Spelling, } \\
\text { Laumert, and } \\
\text { Fransson (2014) }\end{array}$ & Spain & $\begin{array}{l}\text { CSP with TES system in a } \\
\text { particular location: Seville }\end{array}$ & $\begin{array}{l}\text { Optimum power plant } \\
\text { configurations considering different } \\
\text { price-based grid integration } \\
\text { strategies }\end{array}$ \\
\hline $\begin{array}{l}\text { Guédez et al. } \\
\text { (2016) }\end{array}$ & $\begin{array}{l}\text { South } \\
\text { Africa }\end{array}$ & $\begin{array}{l}\text { CSP plant: molten salt solar } \\
\text { tower plants with storage }\end{array}$ & $\begin{array}{l}\text { Multi-objective optimization } \\
\text { (comparative): investment and } \\
\text { profits }\end{array}$ \\
\hline $\begin{array}{l}\text { Izquierdo, } \\
\text { Montanes, } \\
\text { Dopazo, and } \\
\text { Fueyo }(2016)\end{array}$ & Spain & $\begin{array}{l}\text { CSP technologies: parabolic- } \\
\text { trough vs tower plants }\end{array}$ & $\begin{array}{l}\text { Minimal cost objective using } \\
\text { solar multiple, capacity factor and } \\
\text { storage capacity }\end{array}$ \\
\hline $\begin{array}{l}\text { Zhao, Chen, and } \\
\text { Thomson (2017) }\end{array}$ & China & CSP plants & $\begin{array}{l}\text { LCOE and sensitivity analysis using } \\
\text { investment, O\&M cost, production } \\
\text { and discount rate }\end{array}$ \\
\hline $\begin{array}{l}\text { Boukelia, Arslan, } \\
\text { and Mecibah } \\
\text { (2017) }\end{array}$ & Turkey & $\begin{array}{l}\text { Parabolic trough CSP: TES } \\
\text { vs fuel backup system }\end{array}$ & $\begin{array}{l}\text { LCOE analysis (comparative) using } \\
\text { artificial neural network (ANN) } \\
\text { model }\end{array}$ \\
\hline $\begin{array}{l}\text { Yang, Zhu, and } \\
\text { Guo (2018) }\end{array}$ & China & CSP demonstration plants & $\begin{array}{l}\text { Cost-benefit analysis using SP, } \\
\text { NPV, NPVR, and IRR }\end{array}$ \\
\hline
\end{tabular}

nomic lifetime (Zhao et al., 2017). The existing research involving these financial evaluations (see, for instance, Lee, Hong, Koo, \& Kim, 2018) rarely refers to the case of CSP industry. Moreover, the design of models for the performance of CSP plants usually implies the existence of contradictory objectives that leads to final results that has to be offset among them. The problem is that these considerations are not always contemplated in this type of studies. The main goal is the minimization of LCOE through performance indicators for baseload operations. Nevertheless, the incorporation of other goals, such as the maximization of IRR, may enhance the analysis in order to contemplate the actual hour of generation of electricity or dispatchability for peaking operations.

In view of the importance of cost-benefit to the investment decisions and policy making (like, for instance, in the case of lenders), this paper elaborates a comprehensive analysis of all lifetime cost expenditures in order to minimize LCOE for a CSP power plant. In particular, 
it determines a new theoretical framework of the LCOE by introducing the estimation of the shareholder IRR endogenously as a novelty in this kind of analysis. Then, the empirical study firstly estimates the shareholder IRR and secondly discusses the sensitivity factors affecting the model for the cost-benefit evaluation of the Spanish CSP demonstration projects (that is, from a technical, economic, political and also financial perspective). This enhanced approach is a powerful manner to identify the accurate tradeoff between the chosen design objectives (such as the calculation of the shareholder IRR for them to know their expected return on investment) in a given area while at the same time contemplating a comprehensive plant design by means of the calculation of the whole project IRR. In short, the main contribution of this paper is the calculation of IRR from the point of view of the shareholder, which does not include only the current benefits and costs (initial costs, O\&M costs, insurance costs, etc.) but also includes other aspects equally important as depreciation (A), financial costs (F), taxes $(\mathrm{T})$ and bank financing $(\mathrm{E})$.

\section{Modeling the Levelized Cost of Energy (LCOE)}

The mathematical calculation of the LCOE follows a life-cycle technique through a closedform model that in turn can be applied to empirical studies. Thus, section 3.1 estimates the LCOE for the Spanish CSP plants by introducing directly the corresponding real data in the model. Then, section 3.2 carries out a sensitivity analysis for different variables that affect the LCOE in order to notice the relevance of the techno-analysis in renewable energy sector for policy planning. In particular, this model will be applied to the LCOE of CSP plants but it may be extended to basically other energy technologies.

The LCOE defines "the present value of the total cost of building and operating a generating plant over an assumed financial life and duty cycle, converted to equal annual payments, given an assumed utilization, and expressed in terms of real money to remove inflation" (IEA, 2014, p. 17).This value is measured in \$/kilowatt-hour. Unlike other studies, it offers an evaluation of the economic lifetime energy cost and also lifetime energy production, not cost annually (I. Purohit \& P. Purohit, 2010) so all the variables entering the formulas have a precise meaning. We follow the specification of Hernández-Moro and Martínez-Duart (2013) but estimating under this new approach both shareholder IRR (as the novelty in this kind of analysis) and the usually project IRR ${ }^{3}$. The expenses and sales revenues have to be discounted at a present time performing a discounted cash flow (DCF) analysis, i.e., using a discount rate (in this case, shareholder IRR) that reflects the return when the investor breaks even. Therefore, LCOE is calculated when the present value of the discounted total revenues are equivalent to the discounted total costs during the project lifetime.

$$
\sum_{y=0}^{N l}\left(\frac{\text { Revenues }_{y}}{\left(1+i_{\text {shareholder }}\right)^{y}}\right)=\sum_{y=0}^{N l}\left(\frac{\text { Costs }_{y}}{\left(1+i_{\text {shareholder }}\right)^{y}}\right) .
$$

\footnotetext{
${ }^{3}$ Other studies, such as Hernández-Moro and Martínez-Duart (2013), also introduces financial indicators (discount rate which measure the time value of the money and the risk of the investment). The novelty here is to estimate shareholder IRR (not only project IRR) as one of the objectives of the model taking into account not only traditional costs (initial costs, O\&M costs, insurance costs, etc) but also amortization (A), financial costs (F), taxes (TAX) and equity percentage (E) that is inside the total investment (I).
} 
The variables used in this enhanced model for the measurement of LCOE and both the project IRR and the shareholder IRR are defined in Table 2. The model is described below.

Table 2. Measurement of LCOE: factors

\begin{tabular}{|c|c|c|c|}
\hline Parameter & Description & Parameter & Description \\
\hline \multicolumn{2}{|r|}{ Plant dependant Factors } & \multicolumn{2}{|r|}{ General Factors } \\
\hline $\mathrm{P}_{1}$ & Annual Net Electricity Production & S & Annual Insurance Rate \\
\hline $\mathrm{Z}$ & Production load & $\mathrm{T}$ & Annual Income Tax Rate \\
\hline $\mathrm{Nc}$ & Construction period & $\mathrm{Nl}$ & Plant Life \\
\hline AV & Plant Availability & $\mathrm{Fa}$ & Depreciation base \\
\hline $\mathrm{D}$ & Degradation & $\mathrm{Na}$ & Amortization schedule \\
\hline $\mathrm{I}$ & Total investment & \multicolumn{2}{|c|}{ Factors for Financial or Shareholder IRR } \\
\hline $\mathrm{I}_{1}$ & Investment in year 1 & $i_{-}$shareholder & Annual Discount Rate (IRRs $\left.{ }^{\star}\right)$ \\
\hline $\mathrm{O} \& \mathrm{M}_{1}$ & O\&M costs & $\mathrm{r}$ & Bank Interest Rate \\
\hline $\mathrm{i}_{\mathrm{o}}$ & $\begin{array}{l}\text { Annual Discount Rate in O\&M } \\
\text { Costs }\end{array}$ & $\mathrm{E}$ & Equity percentage \\
\hline $\mathrm{p}_{\mathrm{f}}$ & Fuel Price & $\mathrm{Ng}$ & Grace period \\
\hline $\mathrm{C}_{1}$ & Annual fuel consumption in year 1 & $\mathrm{Nf}$ & Bank Financing Period ${ }^{\star *}$ \\
\hline$i_{f}$ & Annual Discount Rate in Fuel Costs & \multicolumn{2}{|c|}{ Factors for Economic or Project IRR } \\
\hline & & i_project & $\begin{array}{l}\text { Annual Discount Rate } \\
\text { (Economic or Project IRR) }\end{array}$ \\
\hline
\end{tabular}

Note $:{ }^{\star}$ IRRs $=$ financial or shareholder IRR; ${ }^{* \star}$ including grace period.

LCOE can be also identified, in terms of Net Present Value (NPV), as the average internal price of energy that must to be sold in order to reach the break-even point throughout the lifetime of the technology (Darling et al., 2011), that is to say, to achieve a zero NPV.

$$
N P V=\sum_{y=0}^{N l}\left(\frac{R t_{y}}{\left(1+i_{\text {shareholder }}\right)^{y}}\right)=0,
$$

where $R t_{y}=B D I_{y}+A_{y}-I_{y}$ (see equation 21), being y the year index and $\mathrm{Nl}$ the selected project lifetime. This estimation inherently considers a fixed discount rate of $i$ for a given time period although the model can be measured under different discount rates. Notice that the project lifetime is key in order to obtain the outcomes.

In this context, the LCOE multiplied by the energy generated annually, $P_{y}$, (being both discounted terms) must be equal to the discounted total costs of the project

$$
\sum_{y=0}^{N l}\left(\frac{L C O E^{\star} P_{y}}{\left(1+i_{\text {shareholder }}\right)^{y}}\right)=\sum_{y=0}^{N l}\left(\frac{\text { Costs }_{y}}{\left(1+i_{\text {shareholder }}\right)^{y}}\right),
$$

where $P_{y}$, being the annual production of energy, with $i=0, \ldots, N l$, requires the fulfillment of this condition: $y-N_{c}$ if $y<N_{c}$ and $y-N_{c}+1$, otherwise, being $y_{i}$ the time in years. Bear in mind that while other previous investigations only consider discount rate $(r)$ and lifetime $(N)$, 
this study differentiates between the year of investment $(y)$ and the year of production $(x)$, because the initial investment occurs at the initial time $(y=0)$ while the period for obtaining benefits usually occur after this initial investment.

Taking into account that the annual value of LCOE is constant:

$$
L C O E=\frac{\sum_{y=0}^{N l}\left(\frac{\text { Costs }_{y}}{\left(1+i_{\text {shareholder }}\right)^{y}}\right)}{\sum_{y=0}^{N l}\left(\frac{P_{y}}{\left(1+i_{\text {shareholder }}\right)^{y}}\right)} .
$$

The above expression can be decomposed between revenues $\left(P_{y}\right)$ and costs (Costs $)_{y}$. Within the revenues, the annual electricity production, $P_{y}$, over the whole lifetime of the project is considered a flow of income and therefore it must be discounted. This production $\left(P_{1}\right)$, in turn, is affected by plant availability (AV), production load (Z), and annual degradation rate $(\mathrm{d})$, obtaining as a result, $P_{y}$. We can express this energy produced for any year $\mathrm{y}$ as follows:

$$
P_{y}=Z_{y}{ }^{*} P_{1}(1-d)^{x-1 *} A V_{y} .
$$

Regarding the costs related to the production, the initial investment $\left(I_{1}\right)$ including both cost of the system and required land are initial capital costs relatively high and variable depending on the market segment that are paid up-front and, in consequence, they are not discounted. However, the operation and maintenance costs $(\mathrm{O} \& \mathrm{M})$, fuel costs $(\mathrm{Fc})$ and insurance costs (IC) must be discounted because they are paid annually as a constant percentage of the production load $(\mathrm{Z})$ :

$$
\begin{aligned}
& \text { O\& } M_{y}=Z_{y}{ }^{\star} \text { O \& } M_{1}{ }^{*}\left(1+i_{o}\right)^{y} ; \\
& F c_{y}=Z_{y}{ }^{\star} C_{1}{ }^{*} p_{\mathrm{f}}{ }^{*}\left(1+i_{f}\right)^{y} ; \\
& I C_{y}=Z_{y}{ }^{\star} S^{\star} I .
\end{aligned}
$$

Therefore, from Eqs (4)-(8), LCOE is rewritten as follows:

$$
L C O E=\frac{I+\sum_{y=1}^{N l}\left(\frac{O \& M_{y}+F c_{y}+I C_{y}}{\left(1+i_{\text {shareholder }}\right)^{y}}\right)}{\sum_{y=1}^{N l}\left(\frac{P_{y}}{\left(1+i_{\text {shareholder }}\right)^{y}}\right)} .
$$

Next, after this technical analysis, and in order to convert this expression into an economic analysis for the numerical estimation of the LCOE (and also the IRR, both the one for the project and the one for the shareholder) it must be shown how the different variables enters into the model for any given lifetime project.

Thus, starting from the total revenues, i.e, the annual electricity production multiplied by LCOE:

$$
P_{y}{ }^{*} L C O E,
$$

we can formulate the Earnings Before Interest, Depreciation, Taxes and Amortization (EBID$\left.\mathrm{TA}_{y}\right)$ : 


$$
\text { EBITDA }_{y}=\left\{\begin{array}{cl}
P_{y}{ }^{\star} L C O E-O \& M_{y}-F c_{y}-I C_{y} & \text { if } y \leq \mathrm{Nl} \\
0 & \text { if } y>\mathrm{Nl}
\end{array} .\right.
$$

Being the depreciation $\left(D_{y}\right)$ :

$$
D_{y}=\left\{\begin{array}{cc}
\frac{1}{\mathrm{Na}} * Z_{y} & \text { if } 0<y \leq N x, \text { where } \sum_{-2}^{N x} D_{y}=1 . \\
0 & \text { in the rest of cases }
\end{array}\right.
$$

Taking into account the amortization ${ }^{4}\left(A_{y}\right)$ :

$$
A_{y}=D_{y} \cdot \mathrm{Fa}^{\star} I \text {, }
$$

we can also calculate the Profit Before Interest and Tax $\left(\mathrm{BAII}_{y}\right)$ :

$$
B A I I_{y}=E B I T D A-A_{y},
$$

where $A_{y}=D_{y}{ }^{\star}$ In this model, in order to obtain the shareholder returns (shareholder IRR) as a novelty, we also consider financial and investment factors. According to the financial costs $\left(F_{y}\right)$, we defined them as:

$$
F_{y}=\left\{\begin{array}{cc}
0 & \text { if } x=0 \\
I \cdot(1-E) \cdot r & \text { if } 0<x \leq N g \\
I \cdot(1-E) \cdot \mathrm{r}\left[\frac{1}{1-(1+r)^{-(N f-N g)}}\right] & \text { if } N g<x \leq N f \\
0 & \text { if } N f<x \leq N l
\end{array} .\right.
$$

Then, the Profit Before Tax $\left(\mathrm{BAI}_{y}\right)$ is obtained as:

$$
B A I_{y}=B A I I_{y}-F_{y} .
$$

Before defining the investment, we can also consider the influence of taxes in the calculation of LCOE by establishing the difference in profits before and after taxes $\left(\operatorname{TAX}_{y}\right)$ :

$$
\operatorname{TAX}_{y}=\left\{\begin{array}{cc}
0 & \text { if } B A I_{y} \leq 0 \\
T \cdot B A I_{y} & \text { if } B A I_{y}>0
\end{array}\right.
$$

and, therefore, the profits after taxes $\left(\mathrm{BDI}_{y}\right)$ are:

$$
B D I_{y}=B A I_{y}-\mathrm{TAX}_{y},
$$

we can also include the above amortization in the BDI expression:

$$
B D I_{y}+A_{y} \text {. }
$$

Finally, the investment $\left(I_{y}\right)$ is derived from the following expression:

$$
I_{y}=\left\{\begin{array} { c l } 
{ I \quad \text { if } N c = 1 } \\
{ \text { if } N c > 1 }
\end{array} \left\{\begin{array}{cl}
\mathrm{E}\left(I_{0}-c \cdot(N c+x)\right) & \text { if } x \leq 0, \\
0 & \text { if } x>0
\end{array}\right.\right.
$$

\footnotetext{
4Te amortization period for goods is fixed by law. In the case of Spain, equipment is assigned by 10 years and constructions by 20 years.
} 
where $c=2 \frac{I_{1} \cdot N c-I}{N c(N c-1)}$, and $I \sum_{y}^{N l} I_{y}$ leads us to obtain $R_{y}$ (see equation 2 ) as the measured used in the determination of the techno-economic analysis of LCOE:

$$
R t_{y}=B D I_{y}+A_{y}-I_{y} \text {. }
$$

The scheme of this theoretical model for LCOE is summarized in the cash diagram expressed jointly with the corresponding equations aforementioned in Figure 1.

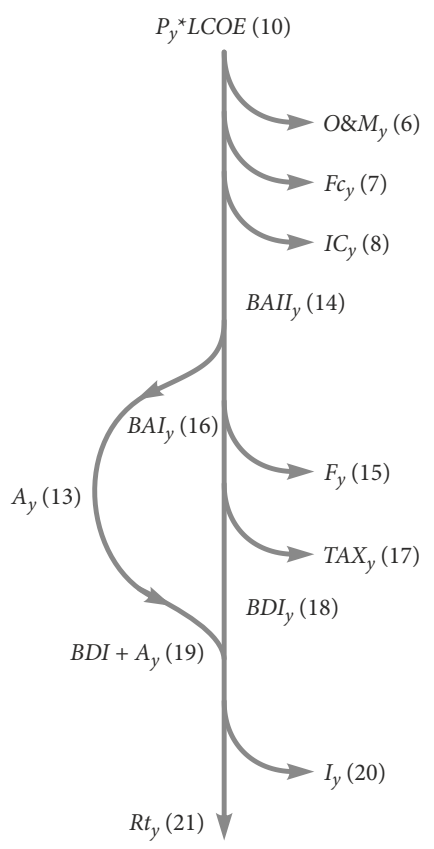

Figure 1. Cash diagram of LCOE

Thus, for the calculation of the shareholder IRR ( $\left.i_{\text {shareholder }}\right)$, we follow this flowchart for each year (y), starting from an initial LCOE. Then, we estimate the sum of the annual $R t_{y}$ values along the lifetime project and we obtained the shareholder IRR from the NPV expression (Equation (2)) taking into account the amortization (A), the financial costs (F), the taxes (TAX) and the equity percentage (E) that is inside the total investment (I). If shareholder IRR coincides with its desired value (for instance, 8\%) we maintain the initial LCOE. Otherwise, we change the LCOE value and perform the same procedure until we obtain the desired shareholder IRR. In other words, we obtain the LCOE that satisfies the desired value for the shareholder IRR. For the case of the project IRR, we implement the same procedure but without including the financial costs $(F)$ nor the equity percentage $(E)$. 


\section{Case of study: the Spanish CSP plants}

CSP technology relies on the aggregation of the solar energy to collect mainly thermal energy which, in turn, serves to produce steam and with it operate a conventional turbine that produces electricity. Despite the fact that nowadays photovoltaic energy has a wider geographic area of application, CSP is able to effectively solve the issues on the instability of solar energy by installing a thermal energy storage (TES) system in the CSP plants (Yang et al., 2018). Besides, some advantages of this CSP technology are: 1) it is manageable or, in other words, it is capable of adapting energy production to demand; 2) it can be combined with fossil fuels, allowing the reduction of emission of polluting gases to the atmosphere in conventional plants, while it can extend its useful life and, 3) it promotes socio-economic development through the creation of employment and industrial fabric that favor technological development, innovation and entrepreneurship. The first aspect is especially important since it offers electricity in times of great need identified with also highest electricity tariff (Stekli, Irwin, \& Pitchumani, 2013).

The generation of energy from CSP plants reached 1,095 MW by the end of 2010. Since then, it has been developed exponentially all around the globe. In spite of the above, its rate of growth has been slower than the officially predicted expectations (IEA, 2014). The market for CSP is determined by direct solar radiation, which is one that comes directly from the sun to the earth's surface without the obstruction of other elements such as particles or clouds. The countries with the highest installed capacity of CSP are Spain and the United States ${ }^{5}$.

Spain is a world leader in the generation of electricity from CSP technologies, representing almost $2 \%$ of the annual production. By the end of 2017 electricity energy balance from CSP was 5,375 GWh and the installed power capacity remained 4,431 MW (Red Eléctrica Española [REE], 2017). The CSP plants turns out to be a viable alternative for the generation of electricity due to their solar resource available and also their effectively capacity to meet the steadily increasing electricity demand profile. Moreover, this technology may diminish the cost of energy in the long-run from the heavy fuel-fossil energies and also the C02 emissions. However, in the last years, the policy regime shift has provoked a paralysis in the RE developments (Martínez Alonso et al., 2016). Under these circumstances, Spain may soon be overtaken by the United States. Thus, for instance the revival of solar power was restricted by the Spanish Government to 2.3. GW under the downturn initiated in 2008. Another example is that CSP plants used natural gas as a backup until the premiums were eliminated, once the policy support was withdrawn for this type of technologies. On the contrary, non-electric CSP increased worldwide almost 5 times from 40GWth in 2000 to $185 \mathrm{GW}$ th in 2010, being the reason behind this rapid growth the public promotion of a green environment in most developed countries (IEA, 2014).

Nowadays, once the public incentives have been removed, the existence of a growing number of new CSP projects is no longer a reality in Spain, even though CSP capacity of $5 \mathrm{GW}$ was envisaged by the national renewable action plan by 2020 (IDAE, 2010). The LCOE of CSP fluctuates at a large extent with the area, technology, design and intended utilization

\footnotetext{
${ }^{5}$ Nonetheless, there is great growth in countries such as South Africa and Morocco, and it is expected that many countries in Latin America, the Middle East and North Africa will also form part of the energy mix.
} 
of plants. In Spain, the current average LCOE is high because their plants presents relatively weak direct normal irradiance (IEA, 2014). In turn, O\&M costs have been evaluated at USD 50/MWh in the CSP plants, considering fuel costs for backup and water consumption for mirror cleaning, feed water make-up and condenser cooling; though the larger the plants, the lower the O\&M costs per MW, benefitting from better solar resource (Kovacic \& Bogataj, 2017).

\subsection{Determination of LCOE for CSP plants in Spain: a new approach}

The case study is based upon a 50MW parabolic trough CSP power plant with 14-hour thermal storage (with molten salts) located in Extremadura (Spain). This empirical study was carried out in 2018. We firstly define in detail the factors involved in the model that directly affect the LCOE present value to implement the theoretical model with the real values they take in this case study. Then, we group them into four dimensions: plant dependant factors, general factors, financial factors and economic factors.

\section{Time variables}

Investing year $(y)$ : it represents the year when the project starts $(y=0)$ and, therefore, when the initial investment is made $\left(\mathrm{I}_{0}\right)$.

Construction period $(\mathrm{Nc})$ : it represents the time it takes to build the plant; in our case study, one year.

Production year $(x)$ : it represents the period in which energy is produced. In our case study, given that the construction lasts one year $(\mathrm{Nc}=1)$, energy is not be produced nor, therefore, sold until one year later $(y=1)$.

Plant life $(\mathrm{Nl})$ : it represents the estimated life time of the plant and its components. For this type of plants, it usually varies between 25 and 30 years.

\section{Investment}

Total investment (I): it corresponds to the total investment needed to carry out the project. In this case study, it refers to a project of $M € 280$. In turn, it can be broken down into:

- Investment year $1\left(I_{1}\right)$ : under this approach, the possibility of not doing all the investment in a single year is contemplated. It may be the case that the investment is distributed throughout the construction period. In this case it is not considered.

- Equity percentage (E): equity share. From the total investment required for the project, it is considered that $70 \%$ is from the shareholder and that the remaining $30 \%$ is financed by the bank, which has a series of financial costs, which will be analyzed later ${ }^{6}$.

\section{Electricity production}

Annual Net Electricity Production (Py): it indicates the net GWh that the plant produces per year, that is, exports to the network.

\footnotetext{
${ }^{6}$ This is one of the main differences with respect to other previous studies (see, for instance, Zhao et al., 2017) since the shareholder never finances $100 \%$ of the investment but rather looks for the banks to finance a part of the project.
} 
- Electricity production of the plant $\left(P_{1}\right)$ : Plant production without degradation and with an availability of $100 \%$. For our reference plant, it was considered $219 \mathrm{GWh}$ /year.

- Degradation (d): since the plant degrades over time, production is affected by this degradation along the time. A degradation of $0.1 \%$ has been considered, which is mainly due to the degradation of the turbine, and to the yield losses of both the heat exchangers and the solar field.

- Production load (Zy): it is related to the production year $(x)$ since it can happen that, if the construction last 2 years, in the last year of construction a certain part of the energy produced can be sold. In this study case, this possibility is not considered.

- Availability (AVy): it considers that the plant never works at $100 \%$ of its capacity due to scheduled stops, maintenance, etc. In addition, this factor may be different during the first years of operation of the plant, since it is also necessary to take into account the learning process of the operators working in the plant. In our case study, $97 \%$ for the first year and $98 \%$ for the rest of years are considered.

\section{Annual costs}

Operation \& Maintenance costs per year (O\&My): it contemplates the costs related to the operation of the plant, the maintenance of the equipment, the cleaning of the solar field, etc and their inflation.

- O\&M costs at year $1\left(\mathrm{O} \& \mathrm{M}_{1}\right)$ : estimated as a $1.5 \%$ of the total investment.

- Annual discount rate in O\&M costs $\left(i_{0}\right)$ : an inflation rate is taken into account for these costs of $1.42 \%$ (annual discount rate).

Fuel costs $(\mathrm{Fc})$ : solar thermal plants also use fuel, both for start-ups and for use on days when solar radiation is low:

- Fuel price $\left(p_{f}\right)$ : the price of fuel at the time this calculation was made was $€ / M W h 50$.

- Annual fuel consumption $\left(C_{1}\right)$ : fuel consumption was estimated at $22 \mathrm{GWh} /$ year.

- Annual Discount rate in fuel costs $\left(i_{0}\right)$ : the fuel inflation rate was estimated at $1.42 \%$.

Insurance costs (IC): due to the risks that exists in this type of project, insurance should be considered and therefore, the costs derived from it:

- Annual insurance rate (S): in this case study, the insurance cost is $1 \%$ of the total investment.

\section{Financial costs}

- Amortization (A): as a novelty, this study considers the amortization

- Amortization schedule ( $\mathrm{Na}$ ): the amortization period is set by law in 15 years.

- Depreciation base (Fa): The applicable base of the amortization is $100 \%$.

- Financial costs (F): this is another fundamental factor in this paper. The financing of a part of the project by the bank has associated costs.

- Bank interest rate (r): the bank interest is $5 \%$ for this project.

- Equity percentage (E): as discussed above, it was 70\% for this project.

- Grace period (Ng): there could be a grace period for the repayment of the debt, but in this study case it is not considered.

- Bank financing period (Nf): period of repayment of the debt (including the grace period), which was 15 years. 
- Annual income tax rate $(\mathrm{T})$ : the tax rate for this type of projects is $30 \%$.

- Annual discount rate (shareholder IRR): normally, it is assumed a shareholder IRR between $8-10 \%$. For this project, it was used as $8 \%$.

- Levelized cost of electricity (LCOE): according to the model, the electricity would have to be sold at 165.9 for the sharedholder to have an IRR of $8 \%$.

According to the above, next, we develop an empirical study for the Spanish CSP plants considered as a case study. In the absence of any public incentives, this empirical study calculates the LCOE on these plants with the aim of assessing different advanced alternatives for unending energy delivery related to the viability of the investment. In the determination of LCOE and, particularly related to risk assuming and financial issues, not only up-front investment cost but shareholder IRR over the project lifetime plays a key role and, therefore, it must be emphasized (Pawel, 2014). However, shareholder IRR and even other assumptions lying beneath are misreported due to the uncertainty revolving around them. For this reason, the measurement of that unpredictability is nowadays away from substantially all LCOE estimations (Darling et al., 2011).Thus, this new approach present estimations for both project IRR and shareholder IRR within a scenario projection for 25 years in Table 3.

In our study case, the evaluation of the LCOE for the CSP plants presented as a case study for Spain requires a total investment of $280 \mathrm{M} €$ within a lifetime of 25 years. It also shows an annual discount rate for the project (economic IRR) of $6.4 \%$ and an annual discount rate for the shareholder (financial IRR) of $8 \%$. Besides, the LCOE achieved a level of $165.90 € /$ MWh. This value will be the benchmark when carrying out the sensitivity analysis of the factors below.

Table 3. Measurement of LCOE: results for CSP plants in Spain

\begin{tabular}{|c|c|c|c|}
\hline Parameter & Value & Parameter & Value \\
\hline \multicolumn{2}{|c|}{ Plant dependant factors } & \multicolumn{2}{|c|}{ General factors } \\
\hline $\mathrm{P}_{1}$ & $219.00 \mathrm{GWh} /$ year & $S$ & $1 \%$ \\
\hline $\mathrm{Z}_{0} ; \mathrm{Z}_{\mathrm{y}>0}$ & $0 \% ; 100 \%$ & $\mathrm{~T}$ & $30 \%$ \\
\hline $\mathrm{Nc}$ & 1 year & Nl & 25 years \\
\hline $\mathrm{AV}_{1} ; \mathrm{AV}_{\mathrm{y}>1}$ & $97 \% ; 98 \%$ & $\mathrm{Fa}$ & $100 \%$ \\
\hline $\mathrm{d}$ & $0.1 \%$ & $\mathrm{Na}$ & 15 years \\
\hline I & $280 \mathrm{M} €$ & \multicolumn{2}{|c|}{ Factors for financial or shareholder IRR } \\
\hline $\mathrm{I}_{1}$ & $257.78 \mathrm{M} €$ & i_shareholder & $8 \%$ \\
\hline $\mathrm{O} \& \mathrm{M}_{1}$ & $4.24 \mathrm{M} € /$ year & $\mathrm{r}$ & $5 \%$ \\
\hline $\mathrm{i}_{\mathrm{o}}$ & $1.42 \%$ & $\mathrm{E}$ & $70 \%$ \\
\hline $\mathrm{p}_{\mathrm{f}}$ & $50 € / \mathrm{MWh}$ & $\mathrm{Ng}$ & 0 \\
\hline $\mathrm{C}_{1}$ & $22 \mathrm{GWh} /$ year & $\mathrm{Nf}$ & 15 years \\
\hline $\mathrm{i}_{\mathrm{f}}$ & $1.42 \%$ & \multicolumn{2}{|c|}{ Factors for economic or project IRR } \\
\hline LCOE & 165.90 & i_project & $6.4 \%$ \\
\hline
\end{tabular}




\subsection{Sensibility analysis for minimizing LCOE value: description and results}

In this study, once the LCOE measure regarding revenues generated from the project cost (for both shareholder IRR and project IRR) is achieved, it can be suggested a quantitative analysis based on input parameter distributions in order to gain better insight into the selection of different alternatives for a given business case. In order to calculate the financial costs, the enhanced LCOE model has been empirically tested by means of a sensitivity analysis to bear in mind not only system costs but also other factors such as financial and banking issues, O\&M costs, or different types of depreciation schedules. Besides, this configuration can be altered in order to incorporate public policy considerations such as taxes or subsidies. Thus, this sensitivity analysis approach led to a simplified comparison of different projects under the consideration of a set of input factors. The results for the CSP plants selected for Spain can be found in Table 4. It describes the usual values of financial variables established by the banks and also economic information from a public tender about a representative sample of CSP plants in Spain 7 .

In the sensibility analysis, fours dimensions are contemplated: plant dependent factors (annual net electricity production, total investment and O\&M costs), general factors (annual insurance rate, annual income tax rate, plant life, and amortization schedule), factors for shareholder IRR (bank interest rate, equity percentage and bank financing period), and

Table 4. Sensitivity analysis: results for the Spanish CSP plants

\begin{tabular}{|c|c|c|c|c|c|c|}
\hline $\begin{array}{l}\text { Descriptive } \\
\text { Variables }\end{array}$ & Factors & $\begin{array}{l}\text { New LCOE } \\
(\text { IRR }=8 \%)\end{array}$ & LRU & $\begin{array}{l}\text { Sensitivity } \\
\text { Parameter }\end{array}$ & $\begin{array}{l}\text { Sensitivity } \\
\text { Value }\end{array}$ & $\begin{array}{l}\text { IRR } \\
\text { project }\end{array}$ \\
\hline $\begin{array}{l}\text { Annual Net } \\
\text { Electricity } \\
\text { Production }^{(a)}\end{array}$ & $\Delta \mathrm{P} 1=20 \%$ & 138.3 & -0.166 & $\Delta \mathrm{LCOE} / \Delta \mathrm{P}_{1}$ & -0.832 & $6.4 \%$ \\
\hline Total investment ${ }^{(\mathrm{a})}$ & $\Delta \mathrm{I}=20 \%$ & 193.4 & 0.165 & $\Delta \mathrm{LCOE} / \Delta \mathrm{I}$ & 0.829 & $6.4 \%$ \\
\hline O\&M Costs ${ }^{(a)}$ & $\Delta{\mathrm{O} \& \mathrm{M}_{1}}_{1}=20 \%$ & 170.5 & 0.028 & $\Delta \mathrm{LCOE} / \Delta \mathrm{O} \& \mathrm{M} 1$ & 0.139 & $6.4 \%$ \\
\hline $\begin{array}{l}\text { Annual Insurance } \\
\text { Rate }\end{array}$ & $\Delta S=20 \%$ & 168.6 & 0.016 & $\Delta \mathrm{LCOE} / \Delta \mathrm{S}$ & 0.081 & $6.4 \%$ \\
\hline $\begin{array}{l}\text { Annual Income } \\
\text { Tax Rate }\end{array}$ & $\Delta \mathrm{T}=20 \%$ & 167.9 & 0.012 & $\Delta \mathrm{LCOE} / \Delta \mathrm{T}$ & 0.060 & $6.3 \%$ \\
\hline Plant Life & $\Delta \mathrm{Nl}=20 \%$ & 164.7 & -0.007 & $\Delta \mathrm{LCOE} / \Delta \mathrm{Nl}$ & -0.036 & $6.9 \%$ \\
\hline $\begin{array}{l}\text { Amortization } \\
\text { schedule }\end{array}$ & $\Delta \mathrm{Na}=20 \%$ & 168.2 & 0.014 & $\Delta \mathrm{LCOE} / \Delta \mathrm{Na}$ & 0.069 & $6.4 \%$ \\
\hline Bank Interest Rate & $\Delta \mathrm{r}=20 \%$ & 168.1 & 0.013 & $\Delta \mathrm{LCOE} / \Delta \mathrm{r}$ & 0.066 & $6.5 \%$ \\
\hline $\begin{array}{l}\text { Equity } \\
\text { percentage }^{(a)}\end{array}$ & $\Delta \mathrm{E}=20 \%$ & 176.0 & 0.061 & $\Delta \mathrm{LCOE} / \Delta \mathrm{E}$ & 0.304 & $7.1 \%$ \\
\hline $\begin{array}{l}\text { Bank Financing } \\
\text { Period }^{(b)}\end{array}$ & $\Delta \mathrm{Nf}=20 \%$ & 164.8 & -0.007 & $\Delta \mathrm{LCOE} / \Delta \mathrm{Nf}$ & -0.033 & $6.3 \%$ \\
\hline
\end{tabular}

Note: (a) important factors if $|\mathrm{LRU}|>2 \%$, (b) including grace period. P is measured in GWh/year; I is measured in €Millions; O\&M is measured in M€/year; LCOE and LRU (LCOE with relative uncertainty) are measured in $€ / \mathrm{MWh}$ and time periods are measured in years.

\footnotetext{
7 This information is confidential and it cannot be provided to the general public.
} 
factors for economic IRR. This analysis has been developed by altering one of the factors (one by one) and calculating the value of the LCOE in order to maintain the shareholder's IRR always at $8 \%$, as it was obtained for the real case study of the CSP plants in Spain. In this way, this analysis seeks to minimize the LCOE not being altered the shareholders' returns (shareholder IRR) in order to guarantee the viability of the project. In order to offer a homogeneous evaluation analysis and following other previous studies (Zhao et al., 2017), the percentage change of each parameter was $20 \%$. The most important factors are expected to be those for which |LRU| is greater than $2 \%$.

From the real LCOE value of 165.9 for the current CSP plants, the sensitivity analysis yields the following results. The variables that lead to a minimization of the LCOE value are not associated to any specific parameter group, and in particular, they are: the annual net electricity production, the plant life and the bank financing period. Thus, the higher their values, the lower the LCOE value (negative sign in their sensitivity values). However, its importance in the contribution to reducing the LCOE is not equivalent. Thus, while the annual net electricity production achieves a LCOE reduction of more than $16 \%$, the other two variables barely achieve a reduction of $0.7 \%$. Regarding the impact on the IRR (economic) project, it would increase similarly in the three cases $(6.4 \%, 6.9 \%$ and $6.3 \%$, respectively).

In the rest of cases, on the contrary, the LCOE value increases as the level of those variable also rises. However, again, these changes are not the same. In particular, it is remarkable the total investments which would increase the LCOE by more of $16 \%$, with a maximum value of 193.4, followed by the equity percentage, with an increase in the LCOE of $6.1 \%$. O\&M costs are also important, although to a lesser extent, since their increase only means an increase of $2.8 \%$ in the LCOE. Other factors such as insurance, taxation, amortization systems or bank financing period have barely shown a significant influence on the changes of the LCOE. The LCOE values (for a fixed shareholder IRR of 8\%) under the variation of the most important factors are represented in Figure 2.

From the above it follows that the most sensitive factors for the LCOE (changes with |LRU| greater than 2\%) are, in most cases, harmful in order to get the minimization of the price of energy. Thus, except for the annual net electricity production, the other three factors (total investments, equity percentage and O\&M costs) contribute to increase the LCOE by a high percentage. The results of this study are in line with the most recent empirical evidence worldwide, which holds that investment costs, O\&M costs, electricity production and discount rate are the most significant variables that affect the LCOE of CSP projects (Hernández-Moro \& Martínez-Duart, 2013; Zhao et al., 2017; Yang et al., 2018). Additionally, in our case, equity percentage also appears as one of the fundamental variables for minimizing the LCOE. There are other branch of studies that focus on factors in particular to establish comparative analyzes, such as Reichling and Kulacki (2008) for the USA, which points out the importance of cost capital or Boukelia et al. (2017) for Turkey, which emphasizes the annual power generation and the capacity factor, also highlighted by I. Purohit and P. Purohit (2010) for India and also by Izquierdo et al. (2016) and Guédez et al. (2014) for Spain, along with the storage capacity. Other variables, however, such as the useful lifetime of the CSP system, have a lower effect on their NPV. 
a)

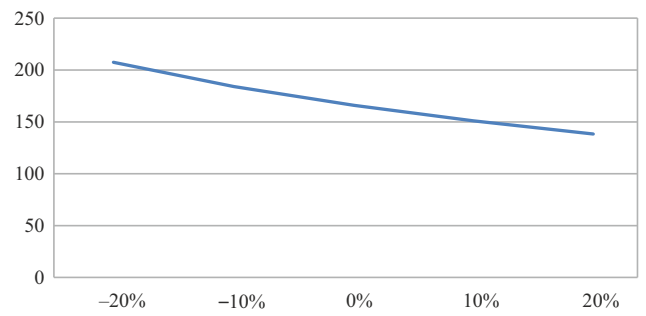

c)

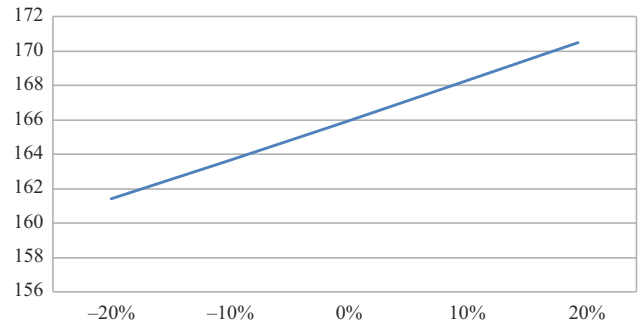

b)

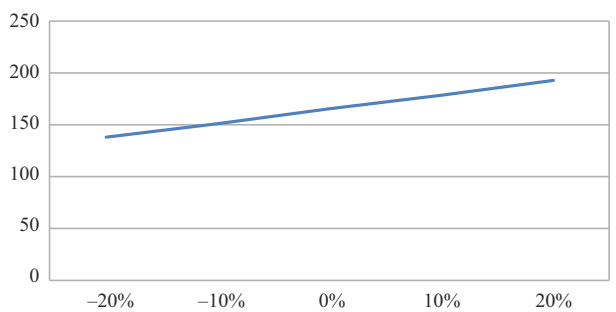

d)

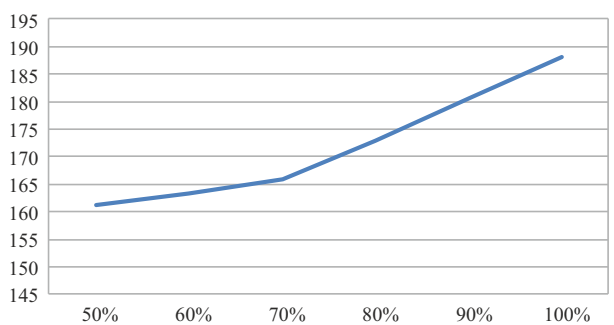

Figure 2. Sensitivity analysis: main results: a - Annual Net Electricity Production; b - Total investment; c - O\&M costs; $d$ - Equity percentage

Overall, these outcomes call attention to the viability of CSP plants as a sustainable alternative for the generation and delivery of electricity in Spain. This technology is remarkable to address the risks of climate change and also to achieve the challenging Sustainable Development Goal number 7 of the United Nations: ensure access to affordable, reliable, sustainable and modern energy for all. Besides, this alternative can strengthen the electricity price stabilization, favoring in this way a decarbonized industry. Thus, more generally, the evaluation of projects in this regard must include not only LCOE estimations but also the expected returns of the shareholders involved in those projects in order to obtain a comprehensive net present value. This comprehensive techno-economic study can add some preeminent scientific groundwork for the investment decisions and policy making of CSP industry in Spain since it includes all the factors contemplated in Table 5, unlike other previous studies where only some of them are contemplated.

Table 5. Factors considered in the analysis of LCOE: empirical evidence

\begin{tabular}{|l|c|c|c|c|c|c|c|c|c|c|}
\hline \multicolumn{1}{|c|}{ Reference } & $\mathrm{Fc}$ & $\mathrm{O} \& \mathrm{M}$ & $\mathrm{I}$ & $\mathrm{IC}$ & $\mathrm{r}$ & $\mathrm{T}$ & $\mathrm{A}$ & $\mathrm{E}$ & $\mathrm{F}$ & BDI \\
\hline $\begin{array}{l}\text { Hernández-Moro and } \\
\text { Martínez-Duart (2013) }\end{array}$ & & $\mathrm{x}$ & $\mathrm{x}$ & $\mathrm{x}$ & & & & & & \\
\hline Li, Liao, Rao, and Liu (2014) & & $\mathrm{x}$ & $\mathrm{x}$ & $\mathrm{x}$ & & & & & & \\
\hline Ouyang and Lin (2014) & & $\mathrm{x}$ & $\mathrm{x}$ & & & & & & & \\
\hline $\begin{array}{l}\text { Ondraczek, Komendantova, } \\
\text { and Patt (2015) }\end{array}$ & & $\mathrm{x}$ & $\mathrm{x}$ & & & & & & & \\
\hline $\begin{array}{l}\text { Yuan, Sun, Zhang, } \\
\text { and Xiong (2014) }\end{array}$ & & $\mathrm{x}$ & $\mathrm{x}$ & $\mathrm{x}$ & $\mathrm{x}$ & & & & & \\
\hline Zhao et al. (2017) & & $\mathrm{x}$ & $\mathrm{x}$ & $\mathrm{x}$ & $\mathrm{x}$ & $\mathrm{x}$ & $\mathrm{x}$ & $\mathrm{x}$ & & \\
\hline
\end{tabular}




\section{Discussion and implications: public incentives vs private investment}

From the previous results, it can be glimpsed whether the public incentives or the private ones favor the minimization of the price of energy, that is, of the LCOE value. At a glance, this study shows that traditional public measures such as taxes or fiscal amortization schemes have a little impact on LCOE. On the contrary, the influence of other private factors such as annual net electricity production or total investment are clearly more effective. These outcomes are aligned with the current empirical evidence at the point that if private stakeholders are empowered to implement a comprehensive evaluation process of these technologies, it is less probable that governments can dominate the energy process (Martínez Alonso et al., 2016) and, therefore, they promote the model of RE generation to a new promising roadmap. Hence, public incentives should relied on other type of government actions more related to production process or investment.

$\mathrm{RE}$ technologies and, in particular, CSP have become increasingly cost-competitive. Besides, the available capital to invest in RE projects all around the world has no shortages with a financial sector that comprises over $€ 100$ trillion of assets. Under this panorama in the private environment, it is hard to believe why investment in RE not growing faster and still is constrained the debt financing for capital-intensive renewable projects ${ }^{8}$. In this regard, contradictory policies, imbalances in electricity markets and investment risk are then the factors explaining the deficiency on investment and innovation in RE (Ang, Röttgers, \& Burli, 2017).

At this political field, enlarge investment in RE demands the design of public incentives in the form of feed-in tariffs (FiTs, i.e., a guaranteed minimum price per unit of RE generated); RE certificates (certifying that one unit of electricity was generated from a RE source, which can be offered in the market independently from the subjacent physical electricity related to a RE generation source); and public tenders (including public competitive bidding or auctions for a set capacity of RE). In this sense, while feed-in tariffs and certificates stimulate investment in most developed economies, auctions and tenders have favored sustainable investment in emerging countries despite the strain from fossil-fuel subsidies in the electricity market. However, at the same time, explicit carbon prices (using emissions trading schemes or taxes) have boosted investment in RE in both advanced and emerging countries, especially in solar energy. Therefore, the alignment of incentives is crucial not only for investment in low-carbon energies but also for innovation in these technologies, finding both positive effects (such as FiTs stimulating renewable patents) and negative ones (such as the combination of setting carbon prices with government RD\&D spending in renewables technologies). On the other hand, public expenditures in research, development and demonstration (RD\&D) has been proved to be a key to promote patents in RE (Polzin, Migendt, Täubec, \& von Flotow, 2015).

Despite this knowledge, public policy in most countries has been moved off from FiTs toward public tenders to adapt it to the conditions of a constantly changing market and also to regulate the development of large-scale RE and reduce prices in the final market. Nevertheless, public RD\&D expenditures are at historic lows with the subsequence negative impli-

\footnotetext{
${ }^{8}$ It is required that annual investment in renewable increase by $150 \%$ until 2050 to fulfil the Paris Agreement's goal of reducing temperature below $2{ }^{\circ} \mathrm{C}$.
} 
cations for innovation. Hence politicians want to articulate incentives and build the requirements from investment policy to competition market policy (including trade and financial considerations) in order to make more attractive to investors the firm commitment to the RE (Table 6). To sum up, targeted public incentives and green policies should encompassed the broader investment and innovation environment for RE. Besides, evidence-based research (as the one provided in this empirical study) and stakeholder cooperation are required to easily design powerful public measures and other related incentives by politicians in order to forward the transformation to a decarbonized economy ${ }^{9}$.

Table 6. Policy drivers for investment flows in renewable power

\begin{tabular}{|l|l|}
\hline \multicolumn{1}{|c|}{ Significant factor } & \multicolumn{1}{c|}{ Description (examples) } \\
\hline Business & Overall ease of doing business \\
\hline Investment policy & $\begin{array}{l}\text { Registering property } \\
\text { Corruption perception } \\
\text { Regulatory quality for solar energy }\end{array}$ \\
\hline Investment facilitation & $\begin{array}{l}\text { Licenses } \\
\text { Permit system }\end{array}$ \\
\hline Competition policy & Direct control of the state over enterprises \\
\hline Trade policy & Ease of trading across borders in the EU \\
\hline Financial market policy & $\begin{array}{l}\text { Access to domestic credit for private sector } \\
\text { Sovereign credit rating } \\
\text { Implementation of Basel III leverage ratio (which aims at restricting } \\
\text { excessive leverage and exposure from banks, constraining access } \\
\text { to long-term financing for capital - intensive RE projects) }\end{array}$ \\
\hline
\end{tabular}

In Spain, the main government support for the generation of electricity from RE (the "Régimen Especial") was initially supported by a price regulation system where the plant operators could select one of the following alternatives: a FiT or a guaranteed premium paid when at the pike of the electricity price on the wholesale market. Thus, Spain has utilized FiTs to favorably boost RE, especially wind and solar. However, EU FiTs programs have been reproved as a mechanism that excessively promote $\mathrm{RE}$ at the expense of higher public expenditures. Because of this and other reasons, after several years as a world leader in the implementation of RE, Spain undergo a rapid deceleration since 2012 when governments removed all the public incentives created to deploy RE creating at that time a paralysis in the entire RE sector. Then, in 2014 for a new support scheme pursued to award a particular compensation regime for new RE plants placed in the electricity system through three competitive call for tenders: 1) a contribution mechanism creating fees for pre-existing and new self-consumption putting in place Renewable Energy Systems (RES) according to levels of capacity and generation (e.g. a tax credit for solar thermal); 2) RES-Electricity operators are empowered to grid connection where a dispatchable energy is prioritized contrary to the grid operator; and 3) policies for training and certification (e.g. financial backing in constructions

\footnotetext{
${ }^{9}$ The number of universities and patents related to RE technologies are both considered in this type of empirical studies.
} 
that are provided from RES). Besides, a new RD\&D plan for the period 2017-2020 intended to promote RES-E, RES-H\&C and RES-T (electricity, heating \& cooling and transport, respectively). Based on the aforementioned, this new public incentives may aim to deploy RES in a more effective way by combining public incentives that encourage private investment in order to achieve a low carbon economy. Only in this way it can be avoided lock-down situations like the one occurred from 2012 in Spain and even be reduced the systemic instability of this sector.

\section{Conclusions}

Decision making in the selection of investment projects related to energy technologies require an extensive financial analysis, involving not only investor but also other stakeholders such as technical professionals and even regulators and policy makers. Despite of its great interest, there is still no well-established methodology to compare costs and returns among different electricity-generating technologies in a comprehensive manner.

This paper introduces a comprehensive methodology in the mathematical model of LCOE for power generation cost calculation by exploring the required system and finance cost needed during the lifetime cycle and the time value of investment. Thus, this technoeconomic research offers a new approach for the calculation of the shareholder IRR that to the best of our knowledge had never been explored before. As a result, the LCOE model constructed in this paper includes not only the traditional plant dependant factors or other general factors but also financial and economic factors such as degradant rate, inflation rate, a breakdown analysis of depreciation and financial costs (grace period, bank financing period, etc.). Moreover, this theoretical model can be used as a reference for the minimization of LCOE in any type of renewable energy power generation technology since the methodology used includes common factors for most of power plants.

CSP plants represent an increasing share in the era of renewable energy and these technologies are especially remarkable in the case of Spain. For those reasons, in the empirical part of the paper we implemented this model for a 50MW parabolic trough CSP power plant with 14-hour thermal storage (with molten salts) located in Extremadura (Spain). This particular technology is the most developed one within the CSP power plants. To do so, general relations within the model were obtained and several factors variations were also discussed. The results obtained from LCOE calculations are highly influenced by the assumptions first set in the analysis. Because of it, the derived model was then used to compare various projects (plants) under different assumptions. Thus, a sensitivity analysis is also performed to establish the influence that market conditions have on the determination of LCOE for different scenarios under the maintenance of a given shareholder IRR for investors. This last assumption makes investment decisions indifferent among several projects in order to focus solely on the minimization of the LCOE. In this way, the richness of the available data allows us to use a wide set of input factors showing, a more adjusted LCOE distribution in order to reduce the uncertainty of the costs associated with a CSP project.

Findings reveal that the minimization of the LCOE value can be achieved under the cooperation of public and private agents based on the alignment of incentives that leads to a low 
carbon economy. Precise public incentives jointly with other greener political measures (such as FiTs and government RD\&D expenditures) should be incorporated in line with a greater drive for private investment and innovation in RE environments. Therefore, a strategic public planning for CSP plants could be of great importance in achieving the goals of RE planning and carbon emission reduction. To do so, the policy design is crucial since not only the type of support instrument but rather its profitability characteristics will influence the investor behavior. Finally, this model has the advantage of readily extending to other technologies in order to compare the returns and costs from different types of energy. In this way, further studies using the new approach outlined in this paper are demanded in order to create a systematic analysis and also quantitative assessment by using LCOE and FCR estimations for diverse business projects and, therefore, its influence on both shareholder and project returns.

\section{Author contributions}

Rogelio Peón Menéndez and Alejandro Parra Martín conceived the study and were responsible for the design and development of the data analysis and also data collection. Laura Varela-Candamio and María-Teresa García-Álvarez were responsible for empirical analysis and data interpretation. Laura Varela-Candamio wrote the first draft of the article.

\section{Disclosure statement}

The usual disclaimer applies.

\section{References}

Ang, G., Röttgers, D., \& Burli, P. (2017). The empirics of enabling investment and innovation in renewable energy. (OECD Environment Working Papers, No. 123). Paris: OECD Publishing. https://doi.org/10.1787/67d221b8-en

Boukelia, T. E., Arslan, O., \& Mecibah, M. S. (2017). Potential assessment of a parabolic through solar thermal power plant considering hourly analysis: ANN-based approach. Renewable Energy, 105, 324-333. https://doi.org/10.1016/j.renene.2016.12.081

Caldés, N., Varela, M., Santamaría, M., \& Sáez, R. (2009). Economic impact of solar thermal electricity deployment in Spain. Energy Policy, 37, 1628-1636. https://doi.org/10.1016/j.enpol.2008.12.022

Darling, S. B., You, F., Veselka, T., \& Velosa, A. (2011). Assumptions and the levelized cost of energy for photovoltaics. Energy \& Environmental Science, 4(9), 3133-3139. https://doi.org/10.1039/c0ee00698j

Dieter, F., \& González, D. M. (2014). Operability, reliability and economic benefits of CSP with thermal energy storage: First year of operation of ANDASOL3. Energy Procedia, 49, 2472-2481. https://doi.org/10.1016/j.egypro.2014.03.262

Hernández-Moro, J., \& Martínez-Duart, J. M. (2013). Analytical model for solar PV and CSP electricity costs: Present LCOE values and their future evolution. Renewable and Sustainable Energy Reviews, 20(4), 119-132. https://doi.org/10.1016/j.rser.2012.11.082

Guédez, R., Spelling, J., Laumert, B., \& Fransson, T. (2014). Optimization of thermal energy storage integration strategies for peak power production by concentrating solar power plants. Energy Procedia, 49, 1642-1651. https://doi.org/10.1016/j.egypro.2014.03.173 
Guédez, R., Topel, M., Conde, I., Ferragut, F., Callaba, I., Spelling, J., Hassar, Z., Pérez Segarra, C. D., \& Laumert, B. (2016). A methodology for determining optimum solar tower plant configuration and operating strategies to maximize profits based on hourly electricity market prices and tariffs. Journal of Solar Energy Engineering, 138(2), 021006. https://doi.org/10.1115/1.4032244

International Energy Agency. (2017). Renewables 2017. Analysis and Forecasts to 2022. Market report series. Retrieved from www.iea.org/Textbase/npsum/renew2017MRSsum.pdf

International Energy Agency. (2014). Technology Roadmap: solar thermal electricity. Retrieved from www.iea.org/publications/freepublications/publication/technologyroadmapsolarthermalelectricity _2014edition.pdf

Izquierdo, S., Montanes, C., Dopazo, C., \& Fueyo, N. (2016). Analysis of CSP plants for the definition of energy policies: the influence on electricity cost of solar multiples, capacity factors and energy storage. Energy Policy, 38(10), 6215-6221. https://doi.org/10.1016/j.enpol.2010.06.009

Kovacic, D., \& Bogataj, M. (2017). Net present value evaluation of energy production and consumption in repeated reverse logistics. Technological and Economic Development of Economy, 23(6), 877-894. https://doi.org/10.3846/20294913.2015.1065455

Lee, M., Hong, T., Koo, C., \& Kim, C.-J. (2018). A break-even analysis and impact analysis of residential solar photovoltaic systems considering state solar incentives. Technological and Economic Development of Economy, 24(2), 358-382. https://doi.org/10.3846/20294913.2016.1212745

Li, Y. Q., Liao, S. M., Rao, Z. H., \& Liu, G. (2014). A dynamic assessment based feasibility study of concentrating solar power in China. Renewable Energy, 69(3), 34-42.

https://doi.org/10.1016/j.renene.2014.03.024

Liu, M., Steven Tay, N. H., Bell, S., Belusko, M., Jacob, R., Will, G., Saman, W., \& Bruno, F. (2016). Review on concentrating solar power plants and new developments in high temperature thermal energy storage technologies. Renewable and Sustainable Energy Reviews, 53, 1411-1432. https://doi.org/10.1016/j.rser.2015.09.026

Lund, P. D. (2011). Boosting new renewable technologies towards grid parity-Economic and policy aspects. Renewable Energy, 36(11), 2776-2784. https://doi.org/10.1016/j.renene.2011.04.025

Martínez Alonso, P., Hewitt, R., Díaz Pacheco, J., Román Bermejo, J., Román Bermejo, L., Hernández Jiménez, V., Vicente Guillén, J., Bressers, H., \& de Boer, C. (2016). Losing the roadmap: renewable energy paralysis in Spain and its implications for the EU low carbon economy. Renewable Energy, 89, 680-694. https://doi.org/10.1016/j.renene.2015.12.004

Nemet, G. F., \& Kammen, D. M. (2007). U.S. energy research and development: declining investment, increasing need, and the feasibility of expansion. Energy Policy, 35(1), 746-755.

https://doi.org/10.1016/j.enpol.2005.12.012

National Research Council. (2010). Hidden costs of energy: unpriced consequences of energy production and use. National Academies Press, Washington, DC. Retrieved from www.ourenergypolicy.org/ wp-content/uploads/2012/06/hidden.pdf

IDAE. (2010). Plan de Acción Nacional de Energías Renovables de España - PANER: 2011-2020. National Renewable Action Plan. IDAE. Ministry of Industry, Tourism and Commerce, Spain. Retrieved from www.idae.es/file/9712/download?token $=6 \mathrm{MoeBdCb}$ (in Spanish).

Ondraczek, J., Komendantova, N., \& Patt, A. (2015). WACC the dog: The effect of financing cost on the levelized cost of solar PV power. Renewable Energy, 75, 888-898. https://doi.org/10.1016/j.renene.2014.10.053

Ouyang, X. L., \& Lin, B. Q. (2014). Levelized cost of electricity (LCOE) of renewable energies and required subsidies in China. Energy Policy, 70(7), 64-73. https://doi.org/10.1016/j.enpol.2014.03.030

Parrado, C., Girard, A., Simon, F., \& Fuentealba, E. (2016). 2050 LCOE (Levelized Cost of Energy) projection for a hybrid PV (photovoltaic)-CSP (concentrated solar power) plant in the Atacama Desert, Chile. Energy, 94(1), 422-430. https://doi.org/10.1016/j.energy.2015.11.015 
Pawel, I. (2014). The cost of storage - how to calculate the levelized cost of storedenergy (LCOE) and applications to renewable energy generation. Energy Procedia, 46, 68-77.

https://doi.org/10.1016/j.egypro.2014.01.159

Polzin, F., Migendt, M., Täubec, A., \& von Flotow, P. (2015). Public policy influence on renewable energy investments - A panel data study across OECD countries. Energy Policy, 80, 98-111. https://doi.org/10.1016/j.enpol.2015.01.026

Purohit, I., \& Purohit, P. (2010). Techno-economic evaluation of concentrating solar power generation in India. Energy Policy, 38, 3015-3029 https://doi.org/10.1016/j.enpol.2010.01.041

Red Eléctrica Española. (2017). The Spanish Electricity System. Preliminary Report 2017. Red Eléctrica Española. Retrieved from www.ree.es/sites/default/files/downloadable/avance_informe_sistema_ electrico_2017_eng.pdf

Reichling, J. P., \& Kulacki, F. A. (2008). Utility scale hybrid wind-solar thermal electrical generation: A case study for Minnesota. Energy, 33(4), 626-638. h https://doi.org/10.1016/j.energy.2007.11.001

Ruiz Romero, S., Colmenar Santos, A., \& Castro Gil, M. A. (2012). EU plans for renewable energy. An application to the Spanish case. Renewable Energy, 43, 322-330. https://doi.org/10.1016/j.renene.2011.11.033

Schleicher-Tappeser, R. (2012). How renewables will change electricity markets in the next five years. Energy Policy, 48, 64-75. https://doi.org/10.1016/j.enpol.2012.04.042

Silinga, C., \& Gauché, P. (2014). Scenarios for a South African CSP peaking system in the short term. Energy Procedia, 49, 1543-1552. https://doi.org/10.1016/j.egypro.2014.03.163

Silinga, C., Gauché, P., Rudman, J., \& Cebecauer, T. (2015). The South African REIPPP two-tier CSP tariff: Implications for a proposed hybrid CSP peaking system. Energy Procedia, 69, 1431-1440. https://doi.org/10.1016/j.egypro.2015.03.119

Spelling, J., \& Laumert, B. (2015). Thermo-economic evaluation of solar thermal and photovoltaic hybridization options for combined-cycle power plants. Journal of Engineering for Gas Turbines and Power, 137(3), 031801. https://doi.org/10.1115/1.4028396

Stekli, J., Irwin, L., \& Pitchumani, R. (2013). Technical challenges and opportunities for concentrating solar power with thermal energy storage. Journal of Thermal Science and Engineering Applications, 5(2), 021011. https://doi.org/10.1115/1.4024143

Tian, Y., \& Zhao, C. Y. (2013). A review of solar collectors and thermal energy storage in solar thermal applications. Applied Energy, 104, 538-553. https://doi.org/10.1016/j.apenergy.2012.11.051

Timilsina, G. R., Kurdgelashvili, L., \& Narbel, P. A. (2012). Solar energy: Markets, economics and policies. Renewable and Sustainable Energy Reviews, 16(1), 449-465. https://doi.org/10.1016/j.rser.2011.08.009

Wagner, S. J., \& Rubin, E. S. (2014). Economic implications of thermal energy storage for concentrated solar thermal power. Renewable Energy, 61, 81-95. https://doi.org/10.1016/j.renene.2012.08.013

Yang, S., Zhu, X., \& Guo, W. (2018). Cost-Benefit analysis for the concentrating solar power in China. Journal of Electrical and Computer Engineering, 2018, 4063691. https://doi.org/10.1155/2018/4063691

Yuan, J. H., Sun, S. H., Zhang, W. H., \& Xiong, M. P. (2014). The economy of distributed PV in China. Energy, 78, 939-944. https://doi.org/10.1016/j.energy.2014.10.091

Zhang, H. L., Baeyens, J., Degrève, J., Cacères, G. (2013). Concentrated solar power plants: review and design methodology. Renewable and Sustainable Energy Reviews, 22, 466-481. https://doi.org/10.1016/j.rser.2013.01.032

Zhao, Z. Y., Chen, Y. L., \& Thomson, J. D. (2017). Levelized cost of energy modeling for concentrated solar power projects: a China study. Energy, 120(1), 117-127.

https://doi.org/10.1016/j.energy.2016.12.122 